\title{
THE ROLE OF GOVERNMENT IN MANAGING SECURITY CHALLENGES: A CASE STUDY OF KADUNA STATE
}

\author{
Abdullahi, I. \\ Department of Geography and Environmental Management, Ahmadu Bello University (ABU), Zaria, Kaduna State, Nigeria. \\ Phone: 07030309798 Email: abdallah82295@gmail.com
}

\begin{abstract}
Insurgencies and other security challenges have caused significant setbacks for sustainable development in Kaduna state. This study assesses the role of the Kaduna state government in managing the security challenges within the state. In this study, significant factors that affects the management of security and its challenges as well as the disposing conditions were critically analyzed. The objective of the study was to examine the managerial effort of the government in tackling security challenges in Kaduna state being critical in the daily running of the state and proposed appropriate measures that could help improve the current situation. Relevant data for this study were collected from both primary and secondary sources. The study employed the exploratory research method. Randomly selected indigenes of Kaduna state from different LGAs comprised the study population out of which 100 questionnaires were administered serving as sample size. The study employed descriptive statistical instruments such as frequencies and percentages in analyzing the obtained data. The study showed that majority $(51.3 \%)$ of the respondents indicated that the government is the most active agent in the fight against insecurity in the state with little corroboration from other agencies. Lack of finance was observed to be the major challenge in the fight against insecurity in the state. Though, most of the state's managerial strategies were credible, yet laudable to some extent. It was however observed that the little corroboration from other agencies such as NGOs, civil societies, traditional rulers and other security agencies played a significant role. The study therefore, recommends that a more inclusive decision-making approach between the state and other agencies be promoted to ensure cross sectional development and fight against insurgencies in the state.
\end{abstract}

Keywords: Government, Kaduna State, management, security challenge, insecurity, sustainable development

LICENSE: This work by Open Journals Nigeria is licensed and published under the Creative Commons Attribution License 4.0 International License, which permits unrestricted use, distribution, and reproduction in any medium, provided this article is duly cited.

COPYRIGHT: The Author(s) completely retain the copyright of this published article.

OPEN ACCESS: The Author(s) approves that this article remains permanently online in the open access (OA) mode.

QA: This Article is published in line with "COPE (Committee on Publication Ethics) and PIE (Publication Integrity \& Ethics)". 


\section{INTRODUCTION}

Nigeria has witnessed an unprecedented plaque of crisis and insecurity, each leading to loss of lives and destruction of properties. According to Ezeoha (2011) in "Causes and effects of insecurity in Nigeria", security means stability and continuity of livelihood, predictability of relationships, feeling safe and belonging to a social group. Internal security can be envisaged as the act of keeping peace within the borders of a sovereign state or other self-governing territories. This is done generally by upholding the national law and defending against internal security threats. There can be no development without security. The nonconventional conception of security lays emphasis on human security. Security according to Fayeye (2011) is the maturation of the structures and processes that can engender and guarantee political space and sufficient conditions for the realization of among other things, personal, group or national aspirations. Thus, security means much more than the absence of conflict.

Kaduna State has from the 1980s occupied a volatile position in the history of sectarian tensions and conflicts in Northern Nigeria. From the early 80s, tensions and conflicts between ethnicities, religions and political parties intensified in Kaduna State. In the broader Nigerian context, several groups have evoked the mobilization of ethnoreligious and, all sorts of identities as vital in the struggle for survival. According to Kazah-Toure (2003), the Babangida years in power, 1985-1993, witnessed the growth of sectarian conflicts. Sectarian conflicts were heightened by the economic crisis that started in 1982, and worsened with the introduction of Structural Adjustment Programme (SAP) from 1986 which sought to privatize companies and balance trade. This brought about the dwindling of people's fortunes, as the poor tend to perceived their enemies as those who belong to the other ethno- religious group rather than the rich who oppress them. Structural Adjustment Programme brought about retrenchment of civil servants from their means of livelihood, inflation, and increase in the cost of living, unemployment and general economic downturn.

\section{AIMS AND OBJECTIVES}

The broad aim of the study was to assess the role of government in managing security challenges in Kaduna state. The specific objectives were to:

i) appraise the challenges of governance in Kaduna state.

ii) appraise the relationship between governance and management of security challenges in Kaduna state.

iii) ascertain the attitude of government of Kaduna state in management of security challenges.

\section{PURPOSE OF RESEARCH}

This research was motivated by the increasing demand for a clear definition of the roles of governments in managing security challenges in Nigeria using Kaduna state as a case study. The findings of the study would provide; a glimpse into the nature of governance in relation to management of internal security challenges, hence providing a solid framework to make further analysis based on the perceptions and attitudes of the indigenes in areas with insecurity. 


\section{RESEARCH JUSTIFICATION}

The government of any state is elected to serve its people, which paramountly, includes ensuring the region is secure. The existing issues of insecurity in the northern states of Nigeria calls for research to study the roles being played by the government and how they can do better. In this study, the relationship between Kaduna state government and the management of security challenges will be ascertained as well as other parameters that might fall-in in terms of ensuring peace and stability in the state. Thus, the study would be of importance to social scientists.

\section{REVIEW OF LITERATURE}

Several studies have been conducted to ascertain the factors influencing insecurities in various regions. This section therefore identifies some factors that contribute to the incessant security challenges from several literatures.

\section{LACK OF INSTITUTIONAL CAPACITY RESULTING IN GOVERNMENT FAILURE}

This result from what Fukuyama (2004) described as the corrosion or breakdown of institutional infrastructures. The foundations of institutional framework in Kaduna State and Nigeria as a whole are very shaky and have provoked a deterioration of state governance and democratic accountability, thus, paralyzing the existing set of constraints including the formal and legitimate rules nested in the hierarchy of social order.

\section{PERVASIVE MATERIAL INEQUALITIES AND UNFAIRNESS}

Greater awareness of disparities in life chances is a major root cause of insecurity in Kaduna State. This is a rooted general perception of inequality and unfairness which has resulted in grievance by a large number of people. This perception stems from the perception of marginalization by a section of the people, government development policies and political offices and this has become a primary source of disaffection and resentment.

\section{ETHNO-RELIGIOUS CONFLICTS}

These have arisen from distrust among various ethnic groups and among the major religions in the country. Ibrahim and Igbuzor (2002), Hazen and Horner, (2007), Salawu (2010) and Igbuzor, (2011) identified ethno-religious conflict as a major source of insecurity in Nigeria. Ethno-religious conflict was defined as a situation in which the relationship between members of one ethnic or religious group and another.

\section{CONFLICT OF PERCEPTIONS BETWEEN THE PUBLIC AND GOVERNMENT}

Over the years, there has been a standing mismatch between public and government perceptions. A situation which often result in the reactions of the public to the excesses of the military regimes which governed Kaduna State and has continued after the end of military regimes and created a sensitivity by those in government at public intrusion in matters of state.

\section{WEAK SECURITY SYSTEM}

This results from inadequate equipment for the security arm of government, both in weaponry and training. This is in addition to poor attitudinal and behavioral disposition of security personnel. In many cases, security personnel 
assigned to deal with given security situations lack the expertise and equipment to handle the situations in a way to prevent them from occurring.

\section{IMPLICATIONS FOR SUSTAINABLE DEVELOPMENT}

Insecurity has been identified as one of the obstacles to sustainable development (Call, 2000, Ujah and Eboh, 2006, Igbuzor, 2011). The term sustainable development was popularized in a report by the Brundtland Commission published by the World Commission on Environment and Development in 1987. In the report, sustainable development was defined as "development which meets the needs of the present without compromising the ability of future generations to meet their own needs (UN, 2010). Since then, the concept has been variously conceived in terms of vision expression, value change, moral development, social reorganization or transformational process toward a desired future or better world (Gladwin et al, 1995).

\section{MATERIALS AND METHODS}

This exploratory research employs a quantitative research design and a structured questionnaire was the primary data collection tool. Data collected were analyzed using statistical tools of frequency distribution and percentages. Quantitative research is the numerical representation and manipulation of observations for the purpose of describing and explaining the phenomena that those observations reflect. It is used in a wide variety of natural and social sciences (Cohen, 1980). In addition, according to Cohen (1980), quantitative analysis is defined as social research tool that employs empirical methods and statements. These attributes make it a suitable device for this research.

\section{POPULATION}

In this study, the population of interest were some 100 indigent residents of Kaduna state without barrier on ethnicity, religion or political affiliation. The researcher gave preference to the population with situational awareness on the pressing issues of security in the state as well as the ways through which the government handles them. This was to ensure high data integrity.

\section{SAMPLE AND SAMPLING TECHNIQUE}

The research was conducted through a systematic random sampling procedure. This is a technique in which the researcher, based on his knowledge and understanding of the population, handpicks certain groups or individuals for their relevance to the subject of investigation (Aina 2001), within the study location. The sample size is 100 and was determined using confidence interval levels.

\section{DATA ANALYSIS}

This chapter presents the data analysis techniques and interpretation of the data obtained from questionnaires distributed to respondents. The questionnaire data were structured to answer the study's research objectives.

\section{RESULTS}

\section{SOCIO DEMOGRAPHIC CHARACTERISTICS}

This section presents the socio-demographic information of the respondents shown in the tables below. 


\section{DISTRIBUTION BY GENDER}

The study sought to establish the distribution of the respondents by gender in the selected population. It was observed that majority $(76.3 \%$ ) of the respondents were male while $23.8 \%$ of the respondents were female. The sharp disparity in gender is due to the fact that women in the study area usually shy away from public engagements and activities such as participating in research studies. More so, some of the female respondents did not return their questionnaires.

Table 1: Table showing distribution by gender

\begin{tabular}{llllll}
\hline & & Frequency & Percent & Valid Percent & Cumulative Percent \\
\hline \multirow{3}{*}{ Valid } & Female & 19 & 23.8 & 23.8 & 23.8 \\
& Male & 61 & 76.3 & 76.3 & 100.0 \\
& Total & 80 & 100.0 & 100.0 & \\
\hline
\end{tabular}

\section{LEVEL OF EDUCATION}

The study also sought to establish the distribution of the respondents by level of educational qualification in the selected population. Majority (27.5\%) of the respondents left school at somewhat the JSS level of education while $8.8 \%$ of the respondents being the minority group had no formal education.

Table 2: Table showing distribution by education level

\begin{tabular}{llllll}
\hline & \multicolumn{1}{c}{ Frequency } & Percent & Valid Percent & Cumulative Percent \\
\hline \multirow{2}{*}{$\begin{array}{lllll}\text { No Formal } \\
\text { Education }\end{array}$} & 7 & 8.8 & 8.8 & 8.8 \\
Valid & 19 & 23.8 & 23.8 & 32.5 \\
& PSS & 22 & 27.5 & 27.5 & 60.0 \\
& SSS & 19 & 23.8 & 23.8 & 83.8 \\
& Tertiary & 13 & 16.3 & 16.3 & 100.0 \\
& Total & 80 & 100.0 & 100.0 & \\
\hline
\end{tabular}

\section{PERCEIVED NATURE OF GOVERNANCE BY THE ADMINISTRATION IN KADUNA STATE}

The study investigated the perception of the sampled population in regard to the performance and nature of governance by the administration in Kaduna state as either a positive or negative performance rating. It was observed that majority $(67.5 \%)$ of the respondents indicated a positive rating while $32.5 \%$ indicated negative rating. This finding shows that majority of the respondents believe that the nature of governance by the administration in Kaduna state was acceptable and commendable. 
Table 3: Table showing distribution by opinions of the nature of governance by the administration in Kaduna state

\begin{tabular}{llllll}
\hline & & Frequency & Percent & Valid Percent & Cumulative Percent \\
\hline \multirow{3}{*}{ Valid } & Negative & 26 & 32.5 & 32.5 & 32.5 \\
& Positive & 54 & 67.5 & 67.5 & 100.0 \\
& Total & 80 & 100.0 & 100.0 & \\
\hline
\end{tabular}

\section{PERCEIVED AREAS OF FOCUS BY THE ADMINISTRATION IN KADUNA STATE}

The study investigated the perception of the sampled population in regard to the areas of developmental focus by the administration in Kaduna state. It was observed that majority (60\%) of the respondents indicated security infrastructure while $40 \%$ of the sample indicated human capital development. The findings show that a majority of the respondents indicated more development in terms of security infrastructures, this was interpreted to mean that more of the respondents had observed more developmental changes in terms of security infrastructures, than in other sectors such as human capital development.

Table 4: Table showing distribution by opinions pertinent to areas of focus by the administration in Kaduna state

\begin{tabular}{llllll}
\hline & Frequency & Percent & Valid Percent & Cumulative Percent \\
\hline \multirow{2}{*}{ Valid } & Human capital & 32 & 40.0 & 40.0 & 40.0 \\
\cline { 2 - 4 } & $\begin{array}{l}\text { development } \\
\text { Security infrastructure }\end{array}$ & 48 & 60.0 & 60.0 & 100.0 \\
& Total & 80 & 100.0 & 100.0 & \\
\hline
\end{tabular}

\section{PERCEIVED RELATIVE EASE OF SOCIO-ECONOMIC ACTIVITIES IN THE STATE RESULTING FROM GOVERNANCE BY THE ADMINISTRATION IN KADUNA STATE}

The study investigated the perception of the sampled population in regard to the perceived relative ease of carrying out socio-economic activities in the state resulting from the governance by the administration in Kaduna State. It was observed that majority (57.5\%) of the respondents ticked "YES" indicating there is relative ease in carrying out socio-economic activities in the state. While, $37.5 \%$ of the population ticked "NO" indicating the contrary.

However, $5.0 \%$ of the sample population were undecided. The findings show that a majority of the respondents had relative ease in carrying out socio-economic activities in the state possibly due to the perceived peaceful state of affairs in the state. 
Table 5: Table showing distribution by opinions pertinent to relative ease of carrying out socio-economic activities in the state due to the perceived peaceful state of affairs in the governance of the state

\begin{tabular}{lllll}
\hline & Frequency & Percent & Valid Percent & Cumulative \\
\hline Yes & 46 & 57.5 & 57.5 & 57.5 \\
No & 30 & 37.5 & 37.5 & 95.0 \\
Undecided & 4 & 5.0 & 5.0 & \\
Total & & & & 100.0 \\
\hline
\end{tabular}

\section{PERCEIVED AREA OF PERSONAL SATISFACTION AS CITIZENS IN THE STATE}

The study investigated the perception of the sampled population in regard to the perceived area of personal satisfaction as citizens in the state resulting from the governance by the administration in Kaduna State. The study sought to establish the distribution of the most beneficial areas of development to the citizens as the government surfaces with new projects and progresses, in the state. It was observed that majority (85.0\%) of the respondents benefited most from human capital development while $15.0 \%$ of the population benefited from security infrastructure. The findings show that majority of the respondents benefited most from human capital development of the state, even though there were development in terms of security infrastructure as seen in Table 4.

Table 6: Table showing distribution by opinions pertinent to the area of personal benefit from the governance in Kaduna State.

\begin{tabular}{llllll}
\hline & Frequency & Percent & Valid Percent & Cumulative Percent \\
\hline \multirow{3}{*}{ Valid } & Human capital development & 68 & 85.0 & 85.0 & 85.0 \\
& Security infrastructure & 12 & 15.0 & 15.0 & 100.0 \\
& Total & 80 & 100.0 & 100.0 & \\
\hline
\end{tabular}

\section{PERCEIVED SECTORIAL CONTRIBUTION TO DEVELOPMENT AND THE FIGHT AGAINST INSECURITY IN THE STATE}

The study investigated the perception of the sampled population in regard to the perceived sectorial contribution to development and the fight against insecurity in the state. It was observed that majority $51.3 \%$ of the respondents indicated government while $8.8 \%$ of the population indicated traditional rulers. The findings show that majority of the respondents believe that the government had more credibly contributed to the development and the fight against insecurity in the state than other sectorial agencies. 
Table 7: Table showing distribution by sector contribution to development and the fight against insecurity in the state

\begin{tabular}{llllll}
\hline & & Frequency & Percent & Valid Percent & Cumulative Percent \\
\hline \multirow{3}{*}{ Valid } & Civil Society & 10 & 12.5 & 12.5 & 12.5 \\
& Traditional Rulers & 7 & 8.8 & 8.8 & 21.3 \\
& Security Agencies & 8 & 10.0 & 10.0 & 31.3 \\
& Government & 41 & 51.3 & 51.3 & 82.5 \\
& Private Organizations & 14 & 17.5 & 17.5 & 100.0 \\
& Total & 80 & 100.0 & 100.0 & \\
\hline
\end{tabular}

\section{RESPONDENTS SUGGESTIONS TO EFFECTIVELY MANAGE SECURITY CHALLENGES IN THE STATE}

The study sought to ascertain the respondent's thoughts and ideas in effectively managing security challenges in the state. This establishes the distribution by suggestions pertinent to the effective management of security challenges in Kaduna state by the government. It was observed that majority (51.3\%) of the respondents suggested that defaulters of the law and insurgents are effectively prosecuted while $15.0 \%$ of the sample suggested sensitization on peace and importance of a secure environment. This infers that lack of persecution of defaulters and allowing criminals to go free is a major contributor to security challenge in the state.

Table 8: Table showing distribution by management suggestion perspectives.

\begin{tabular}{|c|c|c|c|c|c|}
\hline & & Frequency & Percent & Valid Percent & Cumulative Percent \\
\hline \multirow{5}{*}{ Valid } & $\begin{array}{l}\text { Defaulters of law and insurgent's } \\
\text { effective prosecution }\end{array}$ & 41 & 51.3 & 51.3 & 51.3 \\
\hline & $\begin{array}{l}\text { Increase available security } \\
\text { personnel, training and } \\
\text { ammunition. }\end{array}$ & 13 & 16.3 & 16.3 & 67.5 \\
\hline & $\begin{array}{l}\text { Sensitization on peace and } \\
\text { importance of a secure } \\
\text { environment. }\end{array}$ & 12 & 15.0 & 15.0 & 82.5 \\
\hline & $\begin{array}{l}\text { Arming vigilante groups and } \\
\text { training civil society }\end{array}$ & 14 & 17.5 & 17.5 & 100.0 \\
\hline & Total & 80 & 100.0 & 100.0 & \\
\hline
\end{tabular}




\section{DISCUSSION}

From the study, it could be deduced that there are indeed security challenges in the state. However, from Tables 6, it can be observed that the people enjoy significantly from the state of peace in the state due to government intervention as shown. This is in line with the discussions of Gladwell et al. (1995) where they buttressed upon the idea that some government interventions are effective and leads to peace and stability.

Also, findings in this study indicate that there's strong correlation between governance and management of security challenges in Kaduna state as it was observed in Table 4. In which majority (60\%) of the respondents stated that government invested in security infrastructures while $40 \%$ of the sample had indicated human capital.

Table 5 also highlighted the positive attitude of government in managing security challenges in Kaduna state. The respondents indicate that the government has greatly contributed to human capital development, which in turn helps to mitigate the security challenges in the state. They observed that they had personally immensely benefited from human capital development of the state. This is in line with Akin (2008) research of Urban Dynamics, Ethno- Religious Crises and Youth Violence in Kaduna State where he showed how other factors can play a role in secular development to address the issue of insecurity.

Similarly, Table 7 shows $51 \%$ contribution of government contribution to the development and the fight against insecurity in the state. This shows the perceived level of government commitment to ensuing security in the state in relation to other sectors agencies. Though, it was observed that these agencies played a minor role, their impacts were significant. This is in line with the findings of Igbuzor (2011) who concludes that; government approaches to managing security in regions can contribute immensely to sustainable development and collaboration. This study also found out that the attitude of government towards managing security challenges in the state has been positive indicating rapid response and effective interventions.

\section{CONCLUSION AND RECOMMENDATIONS}

From the study, it can be said that the government contributes significantly to the nature of security challenge management seconded by other security agencies employed by the federal government. Also, the study shows that there is positive development in sectorial agencies. The state management security challenges through various sectors such as human capital development, infrastructure and development. The various factors which have been mentioned in the array of solutions as factors to be dealt with include:

\section{GOOD GOVERNANCE}

According to Oluwarotimi (2012), good governance is the panacea for the insecurity challenge in Nigeria. She states that the war against insecurity would be won only by raising governance standards that is, cultivating the culture of good governance where the government is responsible and accountable to the people.

\section{SOCIO-ECONOMIC DEVELOPMENT PLAYS A PART IN ADDRESSING INSECURITY}

In the view of Kufour (2012), the challenge in solving the insecurity problem in Nigeria is to accelerate the pace of development. Development in this context consists of creating an economy with relevant social, economic and 
physical infrastructure for business operations and industrial growth, to provide gainful employment, high level education facilities and medical care for the people.

\section{DEVELOPMENT OF A MORE BALANCED SECURITY STRATEGY TO COUNTER VIOLENT CRIMES AND LOCAL TERRORISM}

This is one of the views of Reddick (Oluwarotimi, 2012). By this, she meant a strategy that is all inclusive and involving a combination of methods that would not only break their communication and interactive network, but also disarm them of resources by tracking their information inflow and resource mobility through higher technology that can also help to locate their base. their sponsors and intelligence power houses and systems (intelligence sources), identifying and isolating them for easy pick.

This study found entrenching good governance, provision of balanced socio-economic status and provision of necessary infrastructure as the means of improving the security in the state. This is consistent with Ukiwo and Chukwuma (2012) who argued that governance deficits and pervasive insecurity in the region are inter-linked and mutually reinforcing.

The following were the recommendations from the study:

1. Government should include and encourage NGOs, civil societies, traditional rulers and other security agencies to do everything within their powers to see that the problem of insecurity is addressed as a regional dichotomy.

2. The infrastructural deficits relevant to security must as a matter of urgency be address forthwith. Above all, every poverty related indicator should be taken care of by the relevant authorities in order to promote human security, freedom and human dignity in the state.

3. Respondents suggested that the government at the state level should treat people of the state equally. It is this equal treatment and opportunities that brings a sense of belonging.

4. Tolerance was also proffered as a probable solution to the incessant conflicts. 


\section{REFERENCES}

Akin, A. (2008). Urban Dynamics, Ethno- Religious Crises and Youth Violence in Kaduna State. Retrieved on $25^{\text {th }}$ April, 2020 from: https://www.hussainiabdu.info/mydocs/urban 12/08/11

Akpobibibo, F. (2003). The Political and Security Implications of Cross Border Migration between Nigeria and Her Francophone Neighbors. International Journal of Social Science Tomorrow, 1(3): 19-25.

Aina, A.J. and Orbih, E. (2001) Information Need and Seeking Behaviour of University Administrators. (1st ed., pp. 12- 13). Lagos University Press, Lagos State.

Call, A. Ujah, H. and Eboh, AB (2009). New Beginnings. Retrieved from: The United Kingdom's Strategy for Countering Terrorism, Retrieved on 25th April, 2020 from: http://www.homeoffice.gov.uk/counter-terrorism

Cohen, L. and Manion, L (1980). Research Methods in Education. London: Groom Helm Ltd.,

Ezeoha, H. (2011). The Proliferation of Small Arms and Light Weapons in Africa: A Case Study of the Niger Delta in Nigeria. Sacha Journal of Environmental Studies, 1(2): 55-80

Fukuyama, F. (2004). State-Building: Governance and World Order in the 21st Century. (2 ${ }^{\text {nd }}$ ed., pp. 123-124) Cornell University Press. Ithaca, New York.

Fayeye, J.O. (2011). Role of the security sector in promoting democratic governance in Nigeria. In Akanji, T.A, Danjibo N.D, Eselebor, W.A, (Eds.) Challenges of democratic governance in Nigeria. Ibadan: John Arches pp. 22-24.

Hazen, J.M. and Horner, J (2007). Small Arms, Armed Violence, and Insecurity in Nigeria: The Niger Delta in Perspective, Switzerland: Small Arms Survey. Journal of Social Science South, 2(13): 6-12

Kazah-Toure (1999), "The Political Economy of Ethnic Conflicts and Governance in Southern Kaduna, Nigeria: [De]Constructing a Contested Terrain. Journal of African Development, 24(2): 109-114.

Salawu, B. (2010). Ethno-Religious Conflicts in Nigeria: Causal Analysis and Proposals for New Management Strategies. European Journal of Social Sciences, 13(3): 345-346

Ukiwo, U and Chukwuma, I. (2012). Governance and insecurity in Southeast Nigeria. 4(2): 8-36. Retrieved on $25^{\text {th }}$ April 2020 from: http://unityjournals.ca/index.php/GISN 